\title{
Prevailing trends of silhouettes in western dresses
}

\author{
VARSHA DEVI AND HARMINDER KAUR SAINI
}

Received: 09.08.2014; Revised: 01.11.2014; Accepted: 16.11.2014

See end of the paper for authors' affiliations HARMINDER KAUR SAINI

Department of Apparel and Textile Science, College of Home Science, Punjab Agricultural University, LUDHIANA (PUNJAB) INDIA

Email: harsaini67@yahoo.com
ABSTRACT : For this study a total of 20 apparel stores were selected purposively and surveyed by the researchers to obtain the information regarding prevailing trends in silhouettes, fabrics, colours and embellishments, etc. for various western dresses. An interview schedule was prepared to study the prevailing trends of western dresses in the local market. The data regarding prevailing trends in western dresses indicated that A-line and balloon silhouettes were available in all the apparel stores. Western dresses in cotton blends and plain (without design) fabrics were available in all the twenty apparel stores. Black coloured western dresses in single and two colour combinations were available in the apparel stores. Yokes, tucks, gathers, pleats, darts were most preferred constructional features as embellishments, dresses with frills and ribbons were available in all the apparel stores.

KEY WORDS: Apparel stores, Western dresses, Prevailing trends

- HOW TO CITE THIS PAPER : Devi, Varsha and Saini, Harminder Kaur (2014). Prevailing trends of silhouettes in western dresses. Asian J. Home Sci., 9 (2) : 527-529. 